\title{
Trends in Markets for Forest-Based Products and Consequences for Selected Countries
}

\author{
Olena Maksymets ${ }^{1}$, Lars Lönnstedt ${ }^{2}$ \\ ${ }^{1}$ Department of International Economic Activity Management, National Forestry University of Ukraine, Lviv, \\ Ukraine \\ ${ }^{2}$ Department of Forest Products, Swedish University of Agricultural Sciences, Uppsala, Sweden \\ Email: alyona.maksymets@gmail.com, lars.lonnstedt@slu.se
}

Received 1 September 2015; accepted 27 September 2015; published 30 September 2015

Copyright (C) 2015 by authors and Scientific Research Publishing Inc.

This work is licensed under the Creative Commons Attribution International License (CC BY). http://creativecommons.org/licenses/by/4.0/

(c) (i) Open Access

\section{Abstract}

The forest sectors in many regions and countries are facing a need to change their structure, due to the development of new markets, emergence of new competitors, and shifts in production and consumption patterns for forest products. This article focuses on recent changes in the trade in these products, on imports and exports of four countries (USA, Sweden, Ukraine and, to a lesser extent, China) during the period from 1995 to 2011. For this purpose we use explanatory data analysis, time series analysis, benchmarking, meta-synthesis and content analysis of scientific and business publications concerning national and global trends in forest product industries. Data sources are various organizations' databases of international trade in forest-based products in both monetary and physical terms (cubic meters and tons). The results show that the US and Swedish forest sectors are adversely affected by downturns in both their domestic and foreign markets during the study period, while the Ukrainian sector maintains exports of low value-added products at roughly constant levels (except that particle-board exports increase). China maintains production quantities of low value-added forest-based products, but also substantially increases exports of high-value added products. The results may facilitate efforts to forecast future trends and provide useful information and methodological approaches for future studies of interest to industry representatives, policy-makers and researchers.

\section{Keywords}

New Markets, Forest-Based Products, Competition, International Trade in Forest Products, Forest Products Companies 


\section{Introduction}

Forest-based products are traded less than many other products, for example only about $20 \%$ of the paper and paperboard produced is traded. Furthermore, traditionally they have been largely traded in local markets. However, global trade has increased with growth in demand and investments in production in emerging markets, including China, India and Eastern Europe (Figure 1 and Figure 2). However, the growth in trade has been far from uniform: demand for some specific products (newsprint, printing and writing paper) has recently declined, and overall demand for the products has remained constant or declined in some major consumer markets (notably North America, Western Europe and Japan). In addition, the scales of multinational companies' activities in the sector have increased. A forest company nowadays may have headquarters in the US, build pulp mills in parts of South America where trees can grow to commercial maturity in less than a decade, and produce paper and paperboard in China to sell in global markets (Alvarez, 2007). These trends have added international dimensions to the industry, which has previously relied mainly on local resources and structures (Jonsson \& Egnell, 2011), prompted needs for changes in the production structure in regions such as North America and northern Europe, and presented new opportunities for emerging exporters, notably in Asia and South America (Figure 1 and Figure 2).

A further factor driving change is that the forest-based industry is an environmentally-sensitive sector that plays a crucial role in global sustainable development, due partly to its unique renewable raw material basis, and partly to its ongoing globalization (Li \& Toppinen, 2011). Hence, the increasing public interest in and global consciousness of environmental and social issues have intensified pressures on forest-based product companies to balance conflicting stakeholder demands, and adjust their business strategies.

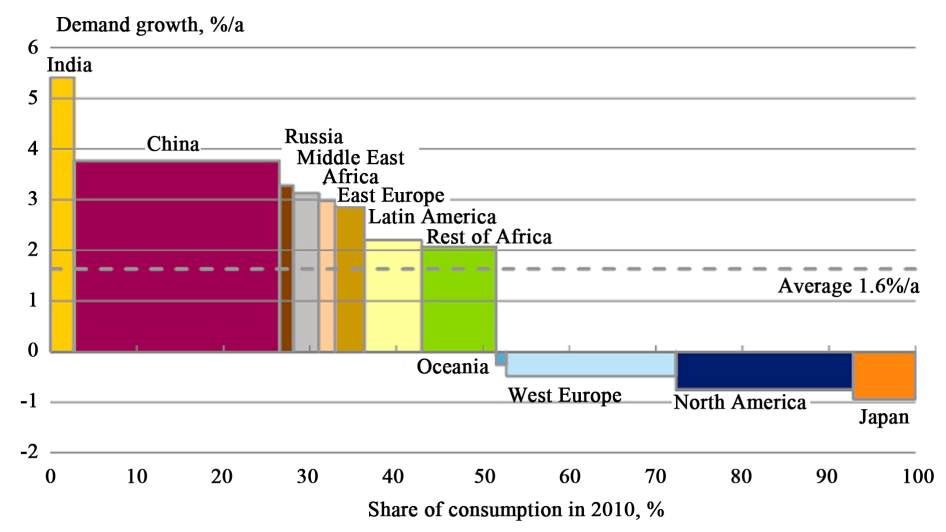

Figure 1. Forecast changes in demands for paper and paperboard in indicated markets until 2025 (source: Pöyry Management Consulting, 2010).

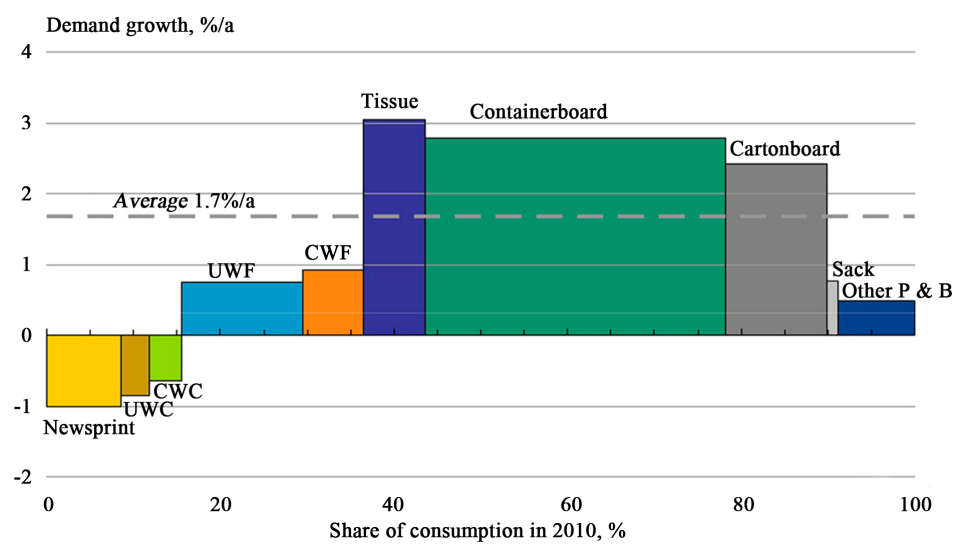

Figure 2. Forecast changes in global demand for specific paper and paperboard (P \& B) products until 2025 (source: Pöyry Management Consulting, 2010). 
The main purpose of this article is to present trends in the export and import patterns of three traditionally important forest product exporting countries (the USA, Sweden and Ukraine) and an emerging competitor (China). The USA and Sweden are selected because they have large forest product industries that have recently been under pressures imposed by financial crisis, changing demand structures and emerging competitors. Ukraine is included because the Ukrainian forest sector has potential to expand its range of exports from roundwood to lumber and particleboard. The Chinese forest products industry is considered to a lesser extent, but included because of its status as an increasingly major player in production and export markets.

In order for the company owners to adjust their strategies rationally (and for policy-makers to formulate appropriate policies), clear understanding of the market trends is required. Hence, robust measures of key variables are needed. For this purpose, Kovalčík (2011) suggested use of measures such as production volumes, value added and profit. Toming (2007) and van Berkum (2009) use indicators-such as exports and imports, net trade balances and foreign direct investment flows - to analyze trade positions of EU-members in the agri-food sector. Various other authors, e.g. Nagubadi \& Zhang (2006), have used a similar approach when studying the sawmilling and wood preservation industries in the USA and Canada. In another approach, Brown \& Ortiz (2001) and Ortiz (2004) studied New Zealand's wood-processing industry's competitiveness and benchmarked it in relation to the Australian, Chilean, Russian, Swedish and US industries. A basic assumption of these authors is that the wood-processing industry in a given country is part of the country's general business environment; thus it is significantly affected by the country's general competitiveness. They also propose a set of specific factors that are particularly relevant for the wood-processing industry (wood resources, wood processing development and industry knowledge, market development, investment attractiveness, energy resources and environmental factors).

A further factor driving change is that the forest-based industry is an environmentally-sensitive sector that plays a crucial role in global sustainable development, due partly to its unique renewable raw material basis, and partly to its ongoing globalization ( $\mathrm{Li} \&$ Toppinen, 2011). Hence, the increasing public interest and global consciousness of environmental and social issues have intensified pressures on forest-based product companies to balance conflicting stakeholder demands, and adjust their business strategies.

\section{Materials and Methods}

The standard trade model is built on four key relationships: 1) the relationship between the production possibility frontier and the relative supply curve; 2) the relationship between relative prices and relative demand; 3 ) the determination of world equilibrium by world relative supply and world relative demand; 4) the effect of the terms of trade, the price of a country's exports divided by the price of its imports, on a nations welfare. Two well-known trade models are The Ricardian model (Ricardo, 1817, 2004) and The Heckscher-Ohlin model (Heckscher \& Ohlin., 1991). In The Ricardian model production possibilities are determined by the allocation of a single resource, labor, between sectors. This model conveys the essential idea of comparative advantage but does not deal with the distribution of income. The Heckscher-Ohlin model includes multiple factors of production which influence trade patterns and distribution of income.

From a business perspective, competitiveness looks somewhat different; other concepts are used. Demand for forest products depends among other things on consumers' utility, willingness to pay and wealth. Culture and habits play also a role. For a specific product from a special company branding plays an important role. Large international companies often have an advantage. Structural changes in consumption will also take place depending on development of new technologies and new products.

From a company perspective competitiveness is influenced by relative prices, own price asked for and competing products prices, including subsidies. Exchange rates, tariffs and transportation costs influence this comparison. The price that a company wants to charge depends on other things, on factor costs as cost of labor, raw material, energy, chemicals and efficiency including labor productivity. Many of these factors the managers can influence through their skills. Important is investments in old and new machines which will contribute to higher efficiency. However, as mentioned above it is not only a question about relative prices other things matters as for example customer relationships, offered service and branding.

The analysis covers general trends in the global market of forest-based products from 1995 to 2012, in order to identify fundamental shifts and facilitate efforts to elucidate factors driving them, and specific trends in the focal countries from 2007 to 2013 . This approach was adopted because industry-level analysis of international trade provides better understanding of structural changes, while examining degrees of specialization can identify comparative advantages or disadvantages (Fetscherin et al., 2012). Furthermore a sector-level analysis enables 
inter-country comparisons, while industry-specific analysis enables intra-country comparisons of specialization and the comparative advantages or disadvantages between and among national industries.

For comparing and discerning trends in trade performance many researchers recommend the use of relative measures, such as: proportional changes in shares of export/import volumes or values; comparative indices of industries' export/import prices, state of trade balances, and trade conditions; import dependency; and/or selfsufficiency or self-reliance ratios (Vichevych \& Maksymets, 2010; Maksymets, 2011, 2012). For each country and each sector, trade performance indices provide indications of its general profile, the country's position or ranking for the specified period, and changes in foreign trade performance during the studied period. The trade performance of individual countries is an indicator of economic performance since generally it is positively correlated with growth in GDP (Mimouni et al., 2007).

Regardless of the absolute measures or relative indices used to assess countries or sectors' trade performance, competitiveness and development, international trade in goods' statistics are important sources of information, and thus widely used by economic analysts and forecasters, as well as governmental and organizational decision-makers (Fabris et al., 2010). They are also used for assessing the openness and integration of countries in international trade, particularly nowadays in terms of globalization (Fabris, 2010). Cadot et al. (2013) conclude that basic facts about a country's economy should include a snapshot of its trade performance. Thus, in our research we have used descriptive, explanatory, multivariate, and time series analysis of key trade statistics, and benchmarking. More specifically, we have used the following indices, which enable assessments of sector-level trade performance and both comparison and benchmarking of forest-based industries of selected countries: the Export Market Share (EMS), Index of Export Concentration (IEC), Index of Import Dependency (IID), Index of State of trade Balance (ISB) and Index of Trade Conditions (ITC).

Export Market Share (EMS) is calculated as

$$
\mathrm{EMS}=\frac{X_{k}}{M_{k}}
$$

$X_{i, k}=$ export from country $i$ of product $k$.

$X_{k}$-Total global export of product $k$.

Export Market Share (EMS) is the value of exports of a focal product from a given country as a percentage of the value of global exports of the product, thus it indicates the country's importance for the product in the global market (OECD reference). A change in a country's share of exports may be due to a shift in its specific sector specialization pattern (structural market effect), a movement into fast-growing markets (market growth effect), a movement out of slowly growing/stagnating markets (market stagnation effect) or other factors not associated with the sectoral distribution of exports (market share effect). The EMS also provides indications of countries' relative capacity advantages and degree of specialization in the market (Richardson, 1971; Milana, 1988; Othman \& Rashid, 1993; Fagerberg \& Srholec, 2004).

Another index that has been used is Index of Export Concentration (IEC) calculated as

$$
\mathrm{IEC}=\frac{X_{k}}{P_{k}}
$$

$X_{k}$-export of product $k$.

$P_{k}$ - production for product $k$.

IEC is the amount (volume or value) of a product that is exported divided by the amount produced, thus a value close to 1 indicates that most of the product produced is exported (Maksymets, 2011, Vichevych \& Maksymets, 2009).

Index of import dependency (IID) is calculated as

$$
\mathrm{IID}=\frac{M_{k}}{C_{k}}
$$

$M_{k}$-import of product $k$.

$C_{k}$ - consumption of product $k$.

IID is the amount of a product imported divided by the amount consumed. Thus, it indicates the share of all consumed goods from a specified sector that were produced abroad. The closer the IID is to 1 the more dependent the country is on imports of this product (op.cit.).

State of trade balance index (ISB) has been calculated as 


$$
\mathrm{ISB}=\frac{X_{k}}{M_{k}}
$$

$X_{k}$-export values of product $k$.

$M_{k}$-import values of product $k$.

ISB is the value of exports of a focal product divided by the value of imports. Thus, if ISB $>1$, export values exceeds import values for the studied product group or individual product (op.cit.).

Another calculation that we have done is Index of Trade Conditions (ITC):

$$
\text { ITC }=\frac{T_{\text {price change } X}}{T_{\text {price change } M}}
$$

$T_{\text {price } X \text { - growth rate of export prices for industry product }}$

$T_{\text {price } M}$ - growth rate of import prices for industry product

The Index of Trade Conditions (ITC) is the change in price of exports of a focal product relative to the change in price of imports in a given period. If ITC $>1$ export prices increased more than import prices, and vice versa if ITC $<1$ (op.cit.). Price is estimated as total value divided by total quantity according to trade statistics.

The following databases have been used in the analysis:

- OECD Stat for the analysis and comparison of export market shares in different sectors of forest-based industries;

- FAOSTAT Forestry for analyzing and comparing trends in production and foreign trade of major forest-based products;

- Statistical databases of the following countries

- Sweden: http://www.statistikdatabasen.scb.se/

- USA: http://www.trademap.org/

- Ukraine: http://www.ukrstat.gov.ua

If not otherwise stated value data have been used.

\section{Results and Discussion}

\subsection{Trade with Forest Industrial Products}

World exports of forest industrial products in USD increased at an average annual rate of $0.5 \%$ during the period 2007-2013, with a major decline between 2008 and 2009 (-21.6\%) and major recovery between 2009 and 2010 $(+19.8 \%)$. This was because the forest products industry was one of the first to face difficulties caused by the financial crisis in 2008, exacerbated (for this sector) by the consequent crash in demand from construction. Between 2012 and 2013 world exports of forest-based products in USD increased by $4.7 \%$, indicating positive shifts in the industry. However, the market share of paper products' and exports of most forest-based products (particularly printing and writing paper) declined during the study period (FAO data,

http://faostat.fao.org/DesktopDefault.aspx?PageID=626\&lang=en\#ancor).

Western countries have and are still dominating trade of forest-based products. However, a comparison between 1995 and 2011 shows that change is taking place (Table 1). A new major player is China. The share for traditional trading countries have with a few exceptions decreased. This index is an indication of different things as structural market effect (capacity growth in South America and Asia), market growth effect (China) and market stagnation effect (Europe and North America). The EMS is also an indication of countries' relative capacity advantages as higher rate of return in South America and China than in North America and Europe (Richardson, 1971; Milana, 1988; Othman \& Rashid, 1993; Fagerberg \& Srholec, 2004).

The Chinese increase was initially due to transfers of manufacturing facilities to China, but in recent years Chinese companies have started to produce substantial volumes of higher value-added forest-based products (Eastin et al., 2012), and every year since 2006 the number of Chinese companies in the top 100 global forestbased products companies has increased (Neale, 2012; PWC, 2013). China has also rapidly achieved a leading position in the global furniture market, with its EMS increasing from $3.8 \%$ in 1995 to $26.6 \%$ in 2011. In contrast, positions of leading manufacturers and exporters of wooden furniture in the late 1990's, such as Germany, Italy, Canada, US, France and Denmark, have declined.

Russia is now the main exporter of unprocessed wood products, as its market share almost tripled during the study period (from $4.3 \%$ in 1995 to over $12 \%$ in 2011), while exports of these products from Canada and the US 
significantly decreased.

Table 2 compares for selected products export as a share of total production (IEC) for 2007 and 2013. Causes for the changes are more or less the same as for EMS. The chosen commodity groups accounted for more than

Table 1. Export Market Shares (EMS) of the top 6 countries in indicated sectors of the forest-based products industry in 1995 and $2011, \%$.

\begin{tabular}{|c|c|c|c|c|c|}
\hline $\begin{array}{l}\text { Paper, paperboard, } \\
\text { articles of paper }\end{array}$ & 1995 & 2011 & Manufactured cork and wood & 1995 & 2011 \\
\hline Germany & 12.08 & 14.98 & China & 3.14 & 14.81 \\
\hline United States & 10.70 & 8.83 & Germany & 5.35 & 7.67 \\
\hline Sweden & 8.15 & 6.71 & Austria & 3.13 & 5.01 \\
\hline Canada & 11.45 & 6.43 & United States & 6.89 & 5.00 \\
\hline Finland & 8.98 & 5.96 & Canada & 7.89 & 4.94 \\
\hline China & 0.84 & 5.30 & Poland & 1.86 & 4.26 \\
\hline TOP-6 aggregated & 52.20 & 48.21 & TOP-6 aggregated & 28.26 & 41.69 \\
\hline Furniture and parts thereof & 1995 & 2011 & Wood, unprocessed cork and wood products & 1995 & 2011 \\
\hline China & 3.79 & 26.64 & Russian Federation & 4.34 & 12.02 \\
\hline Germany & 9.11 & 9.60 & Canada & 25.84 & 9.86 \\
\hline Italy & 18.08 & 9.18 & United States & 15.06 & 8.49 \\
\hline Poland & 3.40 & 6.62 & Sweden & 7.12 & 7.66 \\
\hline United States & 7.84 & 4.63 & Germany & 2.15 & 6.11 \\
\hline France & 4.52 & 2.86 & Austria & 2.71 & 4.13 \\
\hline TOP-6 aggregated & 46.74 & 59.50 & TOP- 6 aggregated & 57.22 & 48.27 \\
\hline
\end{tabular}

Source: http://stats.oecd.org/Index.aspx?QueryId=36403. No data were available for 2012.

Table 2. Index of Export Concentration (IEC) for selected forest-based products (global) in 2007 and 2013, \%.

\begin{tabular}{lcc}
\hline \multicolumn{1}{c}{ Product groups } & $\mathbf{2 0 0 7}$ & $\mathbf{2 0 1 3}$ \\
\hline Paper and paperboard & 30.3 & 27.5 \\
Printing and writing paper & 45.5 & 42.1 \\
Sawnwood (C) & 34.3 & 35.6 \\
Sawnwood (NC) & 20.7 & 17.3 \\
Wood based panels & 32.1 & 24.8 \\
$\quad$ MDF & 31.8 & 18.9 \\
$\quad$ Particle board & 28.6 & 24.3 \\
Plywood & 35.4 & 31.0 \\
Industrial roundwood (C) & 7.8 & 8.9 \\
Industrial roundwood (NC) & 8.1 & 5.4 \\
Wood fuel & 0.3 & 0.4 \\
\hline
\end{tabular}

Source: FAO data http://faostat.fao.org/DesktopDefault.aspx?PageID=626\&lang=en\#ancor. 
three quarters of the total world trade in forest-based products in 2012 ( $76.2 \%$ of imports and $77.3 \%$ of exports) (wooden furniture is excluded because it is difficult to differentiate wood from other material in the data sources).

IEC values of most of the products and product groups declined during the study period, most strongly for non-coniferous sawnwood, wood based panels and non-coniferous roundwood. However, IEC values of coniferous sawnwood and wood fuel increased. The increase in the latter (albeit from a low base) can be explained by growing environmental concerns, for example a goal of the EU is to increase the contribution of renewable energy sources to total primary energy supplies to $20 \%$ by 2020 (European Commission, 2012).

In addition to analyzing and comparing the trade performance of the forest product sectors in the USA, Sweden and Ukraine we have considered the Chinese sector, due to China's rapid economic development and impressive growth of its forest sector. Table 3 and Table 4 show Indices of export concentration and import dependency (IEC and IID, respectively), i.e. values of exports and imports, respectively, of specified products or product groups as percentages of their production values, in the four countries.

IEC values for all Chinese forest-based products declined between 2007 and 2013, which can be explained by higher rises in production volumes compared to export growth rates. Their IID values also decreased, showing that Chinese companies are buying more raw materials for processing. In the USA, IEC values for relatively low value-added forest products increased, but the trends for higher value-added products were more mixed. IEC values for Sweden's major export products (and IID values for printing and writing paper, and coniferous sawnwood) increased. IEC values for several Ukrainian products - including coniferous sawnwood, particle board, coniferous industrial roundwood and wood fuel-increased (however, absolute quantities of some of these products were small).

\subsection{Trade Balance}

1) USA

In 2013 the US forest-based industry companies produced 74.2 million tons of paper and paperboard (2007: 83.9 million tons), 51.1 million cubic meters (CUM) of coniferous sawnwood (2007: 59.8 million CUM) and 18.2 million CUM of non-coniferous sawnwood (2007: 25.6 million CUM). The total export and import values of all US forest-based products were 27,060 million (2007: 20.9 million) and 22,907 million (2007: 27.7 million) USD, respectively (FAO data: http://faostat.fao.org/DesktopDefault.aspx?PageID=626\&lang=en\#ancor).

Table 3. Indices of export concentration (IEC) for indicated forest-based products in China, Sweden, USA and Ukraine in 2007 and $2013, \%$.

\begin{tabular}{|c|c|c|c|c|c|c|c|c|}
\hline \multirow{2}{*}{ Product group/product } & \multicolumn{4}{|c|}{2007} & \multicolumn{4}{|c|}{2013} \\
\hline & China & USA & Sweden & Ukraine & China & USA & Sweden & Ukraine \\
\hline Paper and paperboard & 7.6 & 13.1 & 92.5 & 21.1 & 6.5 & 16.3 & 93.2 & 22.4 \\
\hline Printing and writing paper & 13.0 & 9.8 & 88.1 & - & 13.5 & 15.1 & 98.2 & 0.2 \\
\hline Sawnwood (C) & 3.1 & 2.3 & 60.8 & 58.9 & 1.3 & 8.5 & 73.5 & 86.2 \\
\hline Sawnwood (NC) & 4.5 & 10.7 & 14.9 & 57.9 & 1.0 & 19.0 & 25.2 & 64.4 \\
\hline Wood-based panels & 14.9 & 5.6 & 37.3 & 24.2 & 10.9 & 7.8 & 30.2 & 36.5 \\
\hline MDF & 6.0 & 10.6 & 43.2 & 69.2 & 5.5 & 18.1 & 35.2 & 48.2 \\
\hline Particle board & 2.2 & 2.9 & 14.7 & 18.4 & 1.5 & 3.7 & 10.2 & 31.4 \\
\hline Plywood & 24.1 & 3.6 & 88.0 & 58.7 & 22.9 & 8.9 & 78.8 & 61.2 \\
\hline Industrial roundwood (C) & 0.0 & 2.9 & 5.6 & 28.4 & 0.0 & 7.3 & 1.3 & 48.3 \\
\hline Industrial roundwood (NC) & 0.5 & 1.9 & 0.3 & 47.2 & 0.1 & 2.0 & 4.5 & 21.9 \\
\hline Wood fuel & 0.0 & 0.2 & 1.3 & 8.6 & 0.0 & 0.9 & 0.3 & 10.7 \\
\hline
\end{tabular}

Source: FAO data http://faostat.fao.org/DesktopDefault.aspx?PageID=626\&lang=en\#ancor. 
Table 5 shows Index for state of foreign trade balance (ISB) that relates total export value to total import value for different product groups and individual products. The results show that international trade in US forest-based products was negatively affected by the financial crisis and recession. During the last four studied years the total export value exceeded total import value (ISB $>1$ ). A factor that contributed to this pattern is that commodities with relatively low value-added (industrial roundwood, sawnwood and wood fuel) have very high ISB values, and exports of industrial roundwood exceeded imports almost 22-fold (for hardwood) and almost

Table 4. Indices of import dependency (IID) for selected forest-based products in China, Sweden, USA and Ukraine in 2007 and $2013, \%$.

\begin{tabular}{lcccccccc}
\hline \multirow{2}{*}{ Product group/product } & \multicolumn{4}{c}{$\mathbf{2 0 0 7}$} & \multicolumn{3}{c}{$\mathbf{2 0 1 3}$} \\
\cline { 2 - 8 } & China & USA & Sweden & Ukraine & China & USA & Sweden & Ukraine \\
\hline Paper and paperboard & 7.7 & 17.0 & 55.1 & 53.2 & 4.6 & 13.5 & 57.4 & 43.6 \\
\multicolumn{1}{c}{ Printing and writing paper } & 10.1 & 28.4 & 60.4 & 91.7 & 6.0 & 27.2 & 63.1 & 75.8 \\
Sawnwood (C) & 24.1 & 34.6 & 3.5 & 1.7 & 42.7 & 29.3 & 8.8 & 2.1 \\
Sawnwood (NC) & 21.3 & 5.1 & 62.6 & 1.6 & 17.4 & 5.4 & 40.2 & 1.8 \\
Wood-based panels & 5.0 & 27.5 & 69.3 & 30.5 & 3.0 & 24.6 & 67.5 & 36.5 \\
$\quad$ MDF & 2.0 & 27.6 & 54.4 & 82.0 & 0.6 & 43.3 & 65.1 & 82.3 \\
$\quad$ Particle board & 8.9 & 25.6 & 54.7 & 18.8 & 4.6 & 23.3 & 52.5 & 21.1 \\
$\quad$ Plywood & 5.1 & 26.9 & 96.5 & 41.9 & 4.0 & 26.5 & 93.1 & 39.2 \\
Industrial roundwood (C) & 28.7 & 0.8 & 5.2 & 0.1 & 33.6 & 0.4 & 7.7 & 0.1 \\
Industrial roundwood (NC) & 31.3 & 0.1 & 48.7 & 8.6 & 13.9 & 0.4 & 41.9 & 0.8 \\
Wood fuel & 0.0 & 0.2 & 1.8 & - & 0.01 & 0.3 & 7.8 & - \\
\hline
\end{tabular}

Source: FAO data http://faostat.fao.org/DesktopDefault.aspx?PageID=626\&lang=en\#ancor.

Table 5. Indices of import dependency (IID) for selected forest-based products in China, Sweden, USA and Ukraine in 2007 and $2013, \%$.

\begin{tabular}{|c|c|c|c|c|c|c|c|}
\hline \multirow{2}{*}{ Product group/product } & \multicolumn{7}{|c|}{ Index of state of foreign trade balance } \\
\hline & 2007 & 2008 & 2009 & 2010 & 2011 & 2012 & 2013 \\
\hline Paper and paperboard & 0.74 & 0.81 & 0.76 & 1.08 & 1.13 & 1.08 & 1.08 \\
\hline Printing and writing paper & 0.36 & 0.38 & 0.45 & 0.54 & 0.54 & 0.56 & 0.52 \\
\hline Sawnwood (C) & 0.10 & 0.15 & 0.26 & 0.30 & 0.36 & 0.28 & 0.26 \\
\hline Sawnwood (NC) & 2.20 & 2.11 & 3.17 & 3.58 & 3.76 & 2.77 & 3.85 \\
\hline Wood-based panels & 0.23 & 0.31 & 0.35 & 0.30 & 0.31 & 0.26 & 0.26 \\
\hline MDF & 0.22 & 0.28 & 0.56 & 0.27 & 0.28 & 0.27 & 0.18 \\
\hline Particle board & 0.15 & 0.28 & 0.20 & 0.19 & 0.23 & 0.17 & 0.14 \\
\hline Plywood & 0.09 & 0.14 & 0.16 & 0.14 & 0.15 & 0.13 & 0.21 \\
\hline Industrial roundwood $(\mathrm{C})$ & 4.76 & 10.48 & 17.97 & 26.07 & 38.16 & 21.93 & 40.85 \\
\hline Industrial roundwood (NC) & 26.34 & 27.54 & 17.35 & 28.34 & 26.67 & 20.56 & 21.66 \\
\hline Wood fuel & 0.78 & 1.39 & 1.68 & 2.64 & 4.39 & 3.43 & 2.21 \\
\hline Forest-based products & 0.75 & 0.92 & 1.02 & 1.21 & 1.33 & 1.21 & 1.18 \\
\hline
\end{tabular}

Source: FAO data http://faostat.fao.org/DesktopDefault.aspx?PageID=626\&lang=en\#ancor. 
41-fold (for softwood) in 2013. Exports of hardwood lumber were also almost four times higher than imports. During most of the studied period the value of wood fuel exports was larger than the import value. The ISB for paper and paperboard was also $>1$, because of a significant decline in imports. Thus the industry has become more oriented towards lower value-added wood products, which is not typical for a developed economy with high access to technology, resources, qualified labor and innovative strategic opportunities.

2) Sweden

Sweden is a small country and has only about $1 \%$ of the world's productive forest area. However, the country is a significant exporter of forest-based products.

In 2013 Sweden produced 10.8 million tons of paper and paperboard, 15.8 million CUM of coniferous sawnwood and 0.1 million CUM of non-coniferous sawnwood. The total export and import values for all forest-based products were 16,048 million USD and 2804 million USD (FAO data:

http://faostat.fao.org/DesktopDefault.aspx?PageID=626\&lang=en\#ancor).

The ISB values presented in Table 6 show that the total export value exceeded the total import value by a factor of more than five during the study period, confirming Sweden's strength as an exporter. The highest factors were for coniferous sawnwood (29 - 37 from 2007 to 2012, falling to 22 in 2013), paper and paperboard (about 9.2 - 11.7), and printing and writing paper (6.3 to 9.4). The ISB for MDF varied from 0.9 to 2.0, while values for all other products were much lower. Interestingly, the ISB for wood fuel exceeded 1 in 2007 and 2008, but with the domestic focus on achieving the EU's "20-20-20" target (European Commission, 2012), it subsequently fell well below 1 . One reason for this is the decrease in consumption in both domestic and foreign markets. The value of major export commodities, such as paper and paperboard increased by just $0.2 \%$ p.a., while the value of coniferous sawnwood decreased by $2.4 \%$ p.a. during the study, falling most strongly in 2008, 2009 and 2012. The value of wood-based panel exports also substantially decreased during the studied period. Average export and import prices of Swedish products were higher than global averages, which can be partly explained by the strong Swedish Krona (SEK).

3) Ukraine

In 2013 Ukraine produced 1.1 million tons of paper and paperboard, 1.3 million CUM of coniferous sawnwood and 0.5 million CUM of non-coniferous sawnwood. The total export and import values for all forest-based products were 1327 million and 1174 million USD, respectively (FAO data:

http://faostat.fao.org/DesktopDefault.aspx?PageID=626\&lang=en\#ancor). Thus, compared with the US and Sweden the Ukrainian forest sector is small in both physical and value terms.

The ISB values show that exports of low value-added forest-based products very strongly exceed imports (Table 7). However, it should be remembered that the absolute quantities were small, and the pattern was due to low imports and high exports of raw materials. This is a threat as high quality roundwood and sawnwood are exported while low quality wood is left for domestic manufacturers. However, export values of wood-based panels have increased, following recent foreign investments in manufacturing facilities.

Table 6. Index for foreign trade Balance (ISB) for Swedish forest-based products during 2007-2013.

\begin{tabular}{lccccccc}
\hline \multicolumn{1}{c}{ Product group/product } & \multicolumn{7}{c}{ Index of state of foreign trade balance } \\
\cline { 2 - 7 } & 2007 & 2008 & 2009 & 2010 & 2011 & 2012 & 2013 \\
\hline Paper and paperboard & 9.25 & 9.98 & 10.60 & 10.83 & 11.68 & 10.80 & 11.42 \\
$\quad$ Printing and writing paper & 6.30 & 7.23 & 7.71 & 9.46 & 9.31 & 9.07 & 9.39 \\
Sawnwood (C) & 35.81 & 35.29 & 36.83 & 28.97 & 30.08 & 29.41 & 21.98 \\
Sawnwood (NC) & 0.07 & 0.15 & 0.18 & 0.18 & 0.35 & 0.48 & 0.39 \\
Wood-based panels & 0.50 & 0.53 & 0.53 & 0.42 & 0.36 & 0.37 & 0.37 \\
$\quad$ MDF & 2.02 & 1.92 & 1.65 & 1.32 & 1.23 & 1.19 & 0.90 \\
$\quad$ Particle board & 0.21 & 0.25 & 0.24 & 0.17 & 0.11 & 0.14 & 0.15 \\
\hline
\end{tabular}

Source: FAO data $\underline{\text { http://faostat.fao.org/DesktopDefault.aspx?PageID=626\&lang=en\#ancor. }}$ 


\subsection{Price Changes}

1) USA

Table 8 shows the relationship between changes in export and import prices for the considered products and product groups, which show no clear general pattern. For most products the proportional price changes varied during the study period.

2) Sweden

As shown in Table 9, ITC values for Swedish paper and paperboard, and wood fuel, were $>1$ during the study period, meaning that export prices rose more than import prices. However, for the other products there is no clear general pattern, the ITC values were sometimes $>1$ and sometimes $<1$.

The presented results indicate that exports of sawnwood and printing and writing exports, which are important commodities for the Swedish forest sector, declined during the study period.

Table 7. Index for foreign trade Balance (ISB) for Swedish forest-based products during 2007-2013.

\begin{tabular}{lccccccc}
\hline \multirow{2}{*}{\multicolumn{1}{c}{ Product group/product }} & \multicolumn{7}{c}{ Index of state of foreign trade balance } \\
\cline { 2 - 7 } & 2007 & 2008 & 2009 & 2010 & 2011 & 2012 & 2013 \\
\hline Paper and paperboard & 0.36 & 0.36 & 0.36 & 0.34 & 0.37 & 0.15 & 0.46 \\
Sawnwood (C) & 117.7 & 117.7 & 117.7 & 174.8 & 45.83 & 86.87 & 123.36 \\
Sawnwood (NC) & 63.88 & 46.16 & 31.69 & 33.63 & 59.40 & 51.89 & 70.26 \\
Wood-based panels & 1.08 & 1.08 & 1.23 & 1.21 & 1.07 & 1.18 & 1.02 \\
$\quad$ MDF & 0.05 & 0.06 & 0.31 & 0.35 & 0.22 & 0.28 & 0.31 \\
$\quad$ Particle board & 0.90 & 0.90 & 0.90 & 0.99 & 1.13 & 1.38 & 1.09 \\
$\quad$ Plywood & 2.16 & 2.16 & 3.53 & 2.76 & 2.04 & 1.93 & 1.76 \\
Industrial roundwood (C) & 169.5 & 169.5 & 169.5 & 1646.63 & 8733.19 & 587.11 & 2365.4 \\
Industrial roundwood (NC) & 5.72 & 5.72 & 5.72 & 22.80 & 18.61 & 33.55 & 21.21 \\
Forest-based products & 0.93 & 0.93 & 0.90 & 0.86 & 0.93 & 1.02 & 1.13 \\
\hline
\end{tabular}

Source: FAO data http://faostat.fao.org/DesktopDefault.aspx?PageID=626\&lang=en\#ancor.

Table 8. Index of Trade Conditions (ITC) for US forest-based products, 2007-2013.

\begin{tabular}{|c|c|c|c|c|c|c|}
\hline \multirow{2}{*}{ Product group/product } & \multicolumn{6}{|c|}{ Index of trade conditions } \\
\hline & $2008 / 2007$ & $2009 / 2008$ & $2010 / 2009$ & $2011 / 2010$ & $2012 / 2011$ & $2013 / 2012$ \\
\hline Paper and paperboard & 0.929 & 0.805 & 1.224 & 0.831 & 1.074 & 1.060 \\
\hline Printing and writing paper & 0.941 & 0.976 & 1.047 & 0.979 & 0.905 & 0.993 \\
\hline Sawnwood (C) & 1.020 & 1.039 & 0.857 & 0.979 & 0.888 & 0.686 \\
\hline Sawnwood (NC) & 0.821 & 1.100 & 1.150 & 1.083 & 0.709 & 1.191 \\
\hline Wood-based panels & 0.774 & 1.213 & 0.910 & 1.036 & 0.810 & 0.951 \\
\hline MDF & 0.722 & 2.435 & 0.684 & 0.983 & 0.451 & 1.611 \\
\hline Particle board & 0.853 & 1.105 & 0.987 & 1.107 & 0.968 & 0.627 \\
\hline Plywood & 0.933 & 1.110 & 1.044 & 1.105 & 0.925 & 0.784 \\
\hline Industrial roundwood $(\mathrm{C})$ & 1.216 & 2.883 & 0.419 & 1.024 & 1.100 & 0.839 \\
\hline Industrial roundwood (NC) & 1.712 & 0.425 & 2.874 & 1.015 & 1.318 & 0.934 \\
\hline Wood fuel & 1.025 & 0.973 & 1.126 & 0.953 & 1.000 & 0.864 \\
\hline
\end{tabular}

Source: FAO data http://faostat.fao.org/DesktopDefault.aspx?PageID=626\&lang=en\#ancor. 
3) Ukraine

The ITC values show that exports of low value-added forest-based products very strongly exceed imports (Table 10). Generally average export prices were lower than the import prices, partly reflecting Ukraine's pool of skilled and relatively cheap labor, but the business climate in the country is not regarded as favorable for investment, largely due to the negative image of the country's stability. However, export values of wood-based panels have increased, following recent foreign investments in manufacturing facilities. A conclusion is that Ukraine's forest sector has potential to expand, but this may be hindered by external constraints.

\section{Conclusion}

This article focuses on exports and imports of three selected countries. Forest-based products illustrate recent shifts in consumption, production and international trade. The results show that both the US and Swedish forestbased industries have faced challenges in both their domestic and foreign markets, while Ukraine maintains exports, largely of low value-added products, at a roughly constant level (although particle-board production increases). In contrast, China maintained production volumes of low value-added forest-based products, and substantially increased exports of high-value added products.

Table 9. Index of trade conditions (ITC) for Swedish forest-based products during 2007-2013.

\begin{tabular}{lcccccc}
\hline \multicolumn{1}{c}{ Product group/product } & \multicolumn{5}{c}{ Index of trade conditions } \\
\cline { 2 - 7 } & $2008 / 2007$ & $2009 / 2008$ & $2010 / 2009$ & $2011 / 2010$ & $2012 / 2011$ & $2013 / 2012$ \\
\hline Paper and paperboard & 1.014 & 1.001 & 1.050 & 0.975 & 1.001 & 1.046 \\
$\quad$ Printing and writing paper & 1.091 & 0.981 & 1.027 & 0.922 & 0.981 & 0.964 \\
Sawnwood (C) & 0.951 & 1.145 & 0.993 & 0.960 & 1.145 & 0.872 \\
Sawnwood (NC) & 1.077 & 0.670 & 1.984 & 0.963 & 0.670 & 0.349 \\
Wood-based panels & 0.924 & 1.003 & 1.185 & 0.973 & 1.003 & 0.923 \\
$\quad$ MDF & 0.569 & 1.046 & 1.547 & 0.892 & 1.046 & 0.914 \\
$\quad 1.083$ & 0.947 & 1.140 & 0.937 & 0.947 & 0.983 \\
$\quad$ Particle board & 1.042 & 1.200 & 0.840 & 0.892 & 1.200 & 0.985 \\
Industrial roundwood (C) & 1.137 & 1.146 & 1.011 & 0.963 & 1.011 & 0.942 \\
Industrial roundwood (NC) & 0.764 & 1.420 & 0.445 & 1.487 & 1.927 & 1.151 \\
Wood fuel & 1.070 & 1.950 & 1.410 & 0.691 & 1.042 & 1.119 \\
\hline
\end{tabular}

Source: FAO data http://faostat.fao.org/DesktopDefault.aspx?PageID=626\&lang=en\#ancor.

Table 10. Index of Trade Conditions (ITC) for Swedish forest-based products during 2007-2013.

\begin{tabular}{lcccccc}
\hline \multicolumn{1}{c}{ Product group/product } & \multicolumn{5}{c}{ Index of trade conditions } \\
\cline { 2 - 7 } \multicolumn{1}{c}{} & \multicolumn{1}{c}{ 2008/2007 } & $2009 / 2008$ & $2010 / 2009$ & $2011 / 2010$ & $2012 / 2011$ & $2013 / 2012$ \\
\hline Paper and paperboard & 1.088 & 0.984 & 0.865 & 0.874 & 0.984 & 1.986 \\
Sawnwood (C) & 0.971 & 1.055 & 0.728 & 1.050 & 1.055 & 0.930 \\
Sawnwood (NC) & 1.251 & 0.661 & 0.647 & 0.837 & 0.661 & 0.880 \\
Wood-based panels & 1.021 & 0.824 & 0.828 & 0.914 & 0.824 & 1.078 \\
$\quad 1.195$ & 7.243 & 0.690 & 0.135 & 0.765 & 1.067 \\
$\quad$ MDF & 0.959 & 0.921 & 0.897 & 1.082 & 1.169 & 0.961 \\
$\quad$ Particle board & 1.106 & 0.610 & 0.938 & 0.964 & 0.987 & 0.688 \\
Plywood & 0.885 & 0.879 & 1.272 & 3.154 & 0.879 & 1.391 \\
Industrial roundwood (C) & 1.090 & 1.173 & 0.673 & 0.996 & 1.173 & 1.096 \\
\hline
\end{tabular}

Source: FAO data http://faostat.fao.org/DesktopDefault.aspx?PageID=626\&lang=en\#ancor. 
Our results confirm that the methodological approaches used, based on the theoretical background outlined in Introduction, are valuable tools for analyzing international trade in forest-based products. The results also show that deep analysis is needed for evaluation of forest products industries' international competitiveness.

The findings show that the relative importance of producers, consumers and suppliers of various forest-based products is changing as new markets emerge and locations of production facilities shift (e.g. to China, Chile and Brazil). These changes are already influencing traditionally major forestry countries, such as the USA, Canada and Sweden.

We analyzed the international trade in the selected countries' forest products, assuming that this would partly reflect its competitiveness (in addition to relations between domestic production and consumption). Due to the changes in consumption for some traditional forest products, such as newsprint and printing and writing paper, together with investments in emerging economies such as China and Brazil, we foresee needs for the USA, Canada and Sweden to change the structure of their forest industries.

The results indicate changes in the supply and demand curves. However, based on this study a conclusion about impacts on terms of trade and welfare cannot be drawn. The theory says that, other things equal, a rise in country's terms of trade increases its welfare. Conversely, a decline in a country's terms of trade will leave the country worse off. Growth of the forest sector, i.e. biased growth, leads, other things equal, to an increase in the world relative supply of the goods toward which the growth is based. This shift in the world relative supply curve in turn leads to a change in the growing country's terms of trade, which can go in either direction. If the growing country's terms of trade worsen, this decline offsets some of the favorable effects of growth at home but benefits the rest of the world. The direction of the terms of trade effects depends on the nature of the growth. Growth that is export-biased (growth that expands the ability of an economy to produce the goods it was initially exporting more than it expands the ability to produce goods that compete with imports) worsens the terms of trade. Conversely, growth that is import-biased, disproportionately increasing the ability to produce import-competing goods, improves a country's terms of trade. It is possible for import-biased growth abroad to hurt a country.

The focus for this article was not trade barriers or subsidies. In practice, most countries spend a much higher share of their income on domestically produced goods than foreigners do. This is not necessarily due to differences in taste but rather to trade, natural and artificial barriers, which cause many goods to be nontraded. If nontraded goods compete with exports for resources, transfers will usually raise the recipient's terms of trade. The evidence suggests that this, in fact, is the case. Import tariffs and export subsidies affect both relative supply and demand. A tariff raises relative supply of a country's import good while lowering relative demand. A tariff unambiguously improves the country's terms of trade at the rest of the world's expense. An export subsidy has the reverse effect, increasing the relative supply and reducing the relative demand for the country's export goods, and thus worsening the terms of trade. The terms of trade effects of an export subsidy hurt the subsidizing country and benefit the rest of the world, while those of a tariff do the reverse. This suggests that export subsidies do not make sense for a national point of view and that foreign export subsidies should be welcomed rather than countered. Both tariffs and subsidies, however, have strong effects on the distribution of income within countries, and these effects often weigh more heavily on policy than the terms of trade concerns.

The study could be criticized for the choice of study period. 2007 and 2008 were peak years for the sector that were followed by a period of slow or even decreasing economic development that influenced demand and consumption, not least in western countries. A relevant question to consider is how long the observed tendencies will last. We have examined values that reflect combinations of quantities and prices; thus (for instance) reductions in production or traded quantities may be masked by rises in prices. Changes in exchange rates will also have influenced the results, especially for Sweden and Ukraine. These changes lie outside the control of the forest sector. In addition, use of ratios is problematic as they provide no indications of the direction and scale of changes in the numerators and denominators. It can also be that the quality of the FAO-data is poor for Ukraine and Chine, at least during the first studied years. Nevertheless, the findings of such analyses are potentially valuable for academics and both governmental and organizational decision-makers, particularly when multiple measures corroborate detected trends. Sweden needs to change the structure of their forest industries; development and investment in innovative new products and technologies will also be needed. Such developments are underway (Maksymets, 2012), but their large-scale introduction will take time. For Ukraine a positive shift is observed in the manufacture of wood-based panels, but further progress and investments in environmentallyfriendly technology are needed. 
In this research we did not attempt to estimate the influence of specific factors on trade in forest-based products, because their interactions were highly complex and it was difficult to weigh their importance. Thus, this article can be seen as a first step towards a deeper analysis of factors influencing competitiveness. We have also intentionally restricted the analysis to the sectoral level, but future research should include company-level studies (which must identify and consider key explanatory variables for understanding the complex system of factors that influence successful development of a company's international competitiveness). Future research will focus on detailed analysis of the forest products industry's competitiveness and comparative advantages in selected countries, thereby extending policy prescriptions for improving international competitiveness.

\section{Acknowledgements}

This research was conducted during a scholarship period at the Swedish University of Agricultural Sciences (SLU), with support of a grant from the Swedish Institute. Financial support has also been given from The Swedish Foundation for International Cooperation in Research and Higher Education. We also thank Sees-editing for checking the language and three anonymous referees for very constructive and helpful comments.

\section{References}

Alvarez, M. (2007). The State of America's Forests. Abundant Forests Alliance. Bethesda, MD: Society of American Foresters.

Brown, C., \& Ortiz, G. (2001). The Forest Processing Investment Environment. A Report Prepared for the Ministry of Agriculture and Forestry by Forest Research. Technical Paper No. 01/05.

Cadot, O. ( 2013). A Guide to Trade Data Analysis. In O. Cadot, J.-F. Arvis, T. Farole, J. Gourdon, A. Grover, J. G. Reis, Y. Strachan, \& S. Wagle (Eds.), World Bank's International Trade Department (22 p). Washington DC: The World Bank.

Eastin, I., Cao, J., Ganguly, I., \& Seol, M. (2012). China's Impact on Global Forest-Based Products Trade-Viewpoint from Abroad. Proceedings of the 55th International Convention of Society of Wood Science and Technology, 27-31 August 2012, Beijing, 16 p.

European Commission (2012). Environment Action Programme. http://ec.europa.eu/clima/news/articles/news 2012112901 en.htm

Fabris, N. (2010). Montenegrin Foreign Trade Statistics Analysis Using General and Special Trade Systems Data on International Trade Are an Important Indicator of the Economic Openness and Development of a Country. In N. Fabris, B. Kilibarda, \& M. Radunović (Eds.), Working Papers (p. 18), Podgorica: Central Bank of Montenegro.

Fagerberg, J., \& Srholec, M. (2004). Structural Changes in International Trade. Revue économique, 6, 1071-1097.

Fetscherin, M., Alon, I., Johnson, J. P., \& Pillania, R. K. (2012). Export Competitiveness Patterns in Indian Industries. Competitiveness Review: An International Business Journal Incorporating. Journal of Global Competitiveness, 22, 188206.

Heckscher, E. F., \& Ohlin, B. G. (1991). Heckscher-Ohlin Trade Theory. Cambridge, MA: The MIT Press.

Jonsson, R., Egnell, G., \& Baudin, A. (2011). Swedish Forest Sector Outlook Study. Geneva Timber and Forest Discussion Paper 58, Geneva: United Nations Economic Commission for Europe, Rome: Food and Agriculture Organization of the United Nations.

Kovalčík, M. (2011). Profitability and Competitiveness of Forestry in European Countries. Journal of Forest Science, 57, 369-376.

Li, N., \& Toppinen, A. (2011). Corporate Responsibility and Sustainable Competitive Advantage in the Forest-Based Industry: Complementary or Conflicting Goals? Forest Policy and Economics, 13, 113-123.

Maksymets, O. (2011). The Evaluation of Competitive Advantage of Ukraine in Forest-Based Products International Trade during Modern Economic Crisis. International Trade: Economics, Finance, Law. Scientific Journal, 4-5. (In Ukrainian)

Maksymets, O. (2012). The Study of the Changes in Ukraine's Foreign Trade Geography for Wood Forest-Based Products under the Influence of Economic Crisis and Environmental Initiatives. Scientific Almanac of National Forestry University of Ukraine, 22, 125-136. (In Ukrainian)

Milana, C. (1988). Constant-Market Shares Analysis and Index Number. European Journal of Political Economy, 4, $453-478$. http://dx.doi.org/10.1016/0176-2680(88)90011-0

Mimouni, M., Fontagné, L., von Kirchbach, F., Conte, K., Freudenberg, M., \& Pasteels, J.-M. (2007). The Trade Performance Index. Geneva: Market Analysis Section International Trade Center (ITC). 
Nagubadi, R. V., \& Zhang, D. (2006). Competitiveness in the Sawmills and Wood Preservation Industry in the United States and Canada. Forest Science, 52, 340-352

Neale, D., Murdoch, I., Bromley, K., \& Legg, K. (2012). Global Forest, Paper \& Packaging Industry Survey—Survey of 2011 Results. London: PWC.

Ortiz, G. A. (2004). Benchmarking the Competitiveness of the New Zealand Wood Processing Industry (53 p). Report Prepared for the Ministry of Agriculture and Forestry (MAF) by Forest Research, Wellington: MAF.

Othman, M., \& Rashid, Z. A. (1993). Constant Market Share Analysis of the ASEAN Timber Trade Theory Pertanika. Journal of Social Science \& Humanities, 1, 71-80.

Price Waterhouse Coopers (2013). http://www.pwc.com/gx/en/forest-paper-packaging/index.jhtml

Ricardo, D. (1817/2004). The Principles of Political Economy and Taxation. New York: Dover.

Richardson, J. D. (1971). Constant-Market Shares Analysis of Export Growth. Journal of International Economic, 1, $227-$ 239. http://dx.doi.org/10.1016/0022-1996(71)90058-4

Toming, K. (2007). The Impact of EU Accession on the Export Competitiveness of Estonian Food Processing Industry. Post-Communist Economies, 19, 187-207.

Vichevych, A., \& Maksymets, O. (2009). International Economic Activity Analysis (2nd ed.). Kyiv, Professional Publishing. (In Ukrainian) 